\title{
PLAZMA METALIZACIJA U VAZDUHU
}

\author{
Vladimir D. Pavkov*, \\ Gordana M. Bakić2, \\ Vesna Maksimović1, \\ Branko Matović1, \\ Miloš Đukić
}

\author{
'Institut za nuklearne nauke „Vinča”, \\ Univerzitet u Beogradu, \\ Beograd, Srbija \\ ${ }^{2}$ Mašinski fakultet, \\ Univerzitet u Beogradu, \\ Beograd, Srbija
}

Odgovorno lice:

Vladimir D. Pavkov

e-pošta:

pavkow@vin.bg.ac.rs

\section{Rezime:}

Danas, kao i prethodnih godina, produžetak radnog veka mašinskih delova i konstrukcija u cilju smanjenja troškova održavanja postrojenja od izuzetne je važnosti za industriju. S obzirom da su delovi u industriji, tokom eksploatacije, izloženi različitim radnim uslovima, kao što su trenje, korozija, abrazija, erozija i drugi oblici habanja, koji dovode do njihovog oštećenja kao i gubitka materijala na površini. Postupci zaštite površinskih slojeva materijala danas su različiti, a jednu značajnu grupu čine postupci metalizacije, pomoću kojih se rastopljeni ili omekšani dodatni materijal nanosi na pripremljenu površinu supstrata formirajući prevlaku različite namene. Imajući u vidu sve postupke metalizacije, plazma metalizacija predstavlja postupak sa najvišom temperaturom u procesu nanošenja prevlake. Visok kvalitet dobijenih prevlaka, omogućava primenu plazma metalizacije u gotovo svim granama industrije. $\mathrm{U}$ ovom radu, predstavljen je princip rada, područje primene, prednosti i nedostaci kao i značaj plazma metalizacije u vazduhu, kao najčešće korišćenog postupka plazma metalizacije.

Ključne reči:

metalizacija, plazma metalizacija u vazduhu, APS, prevlake, prah.

\section{UVOD}

Tokom eksploatacije mašinskih delova i opreme, neminovni su gubici površinskih slojeva materijala, kao posledica izlaganja različitim režimima rada. Površinski gubici materijala najčešće se prepisuju mehaničkim, hemijskim, biološkim kao i drugim pokretačkim procesima koji iniciraju oštećenje. Loše konstrukciono rešenje, u vidu izbora materijala, dovodi do njegove smanjene postojanosti u eksploataciji, pa se različitim postupcima prevlačenja površine na površinu materijala nanose zaštitne prevlake, kako bi se nadomestili novonastali površinski gubici.

Formirane prevlake, na mašinskim delovima, doprinose povećanju otpornosti na određene uslove rada kao što su različiti oblici habanja i trenja, visoke temperature, korozija ili agresivna sredina, što direktno omogućava izlaganje oštrijim režimima rada. Prevlake se mogu nanositi kako u procesu proizvodnje novih delova, tako i u procesu reparacije kod oštećenih površinskih slojeva u slučaju kada stepen oštećenja nije prevelik. 
U današnje vreme, sve je teže izabrati optimalan postupak za nanošenje zaštitnih prevlaka, imajući u vidu da se oni iz dana u dan unapređuju i konstruišu, međutim postupci metalizacije predstavljaju i dalje najčešći izbor u zaštiti površinskih slojeva materijala u industriji. Osnovna namena razvoja metalizacije bila je poboljšanje triboloških svojstava materijala kao i zaštite od različitih oblika korozije, gde i danas ima dominantnu primenu.

\section{METALIZACIJA}

Metalizacija se može definisati kao proces, koji obuhvata niz različitih postupaka, pomoću kog se omekšane ili rastopljene čestice materijala, raspršivanjem, nanose na pripremljenu površinu radnog dela, gde formiraju prevlaku različite namene, Slika 1 [1].

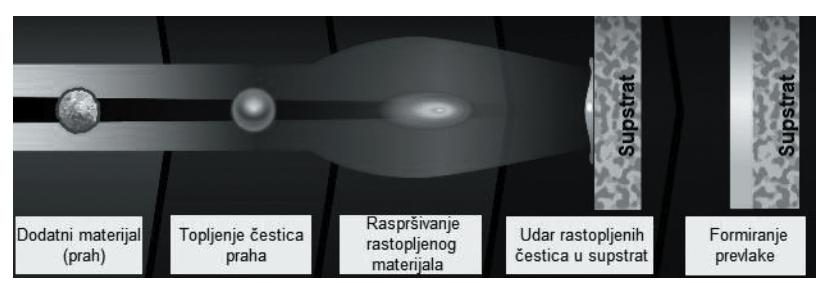

Slika 1. Proces formiranja prevlake primenom metalizacije [2]

Procesom metalizacije dobijaju se prevlake znatno manje debljine u odnosu na materijal na koji se nanose, što će dovesti samo do promene površinskih svojstava metaliziranog dela. U zavisnosti od postupka metalizacije, dodatni materijal, koji služi za formiranje prevlake, može da bude u obliku praha, žice ili šipke, a koji od oblik će biti primenjen zavisi od samog postupka. Slojevi u prevlakama, dobijeni procesom metalizacije, naročito primenom praha kao materijala za formiranje prevlake, su heterogeni i anizotropni. Uspešno nanošenje prevlake prvenstveno zavisi od pravilnog sprovođenja tehnologije metalizacije kao i izbora dodatnog materijala prema opterećenju mašinskog dela i uslova rada.

Jedna od podela postupaka metalizacije, Slika 2, jeste prema vrsti energije koja omogućava topljenje ili omekšavanje dodatnog materijala.

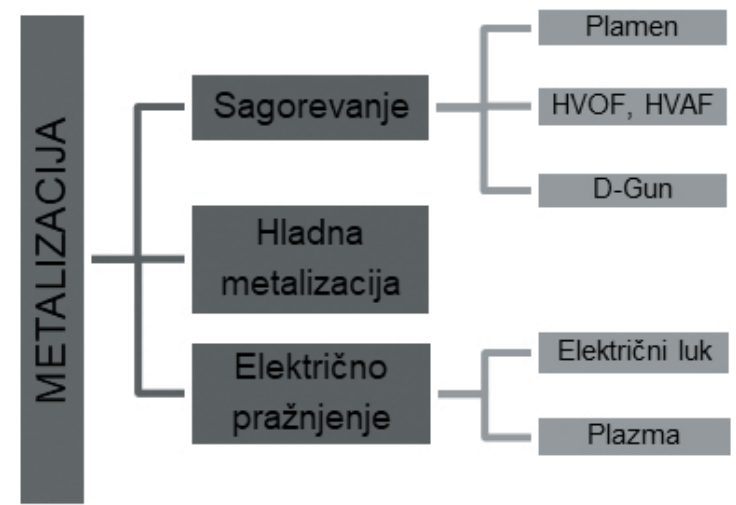

Slika 2. Podela postupaka metalizacije prema vrsti energije

Izbor postupka metalizacije je u funkciji zahtevanih karakteristika slojeva prevlake (gustina, tvrdoća, prianjanje, debljina sloja), radnih delova (geometrija, osnovni materijal, površinski sloj), radnih uslova kao i lokacija na kojoj će biti izvršena metalizacija. U najzahtevnijim slučajevima površinske zaštite materijala, najviše se primenjuju HVOF metalizacija i plazma metalizacija.

Prevlake nanete postupcima metalizacije imaju veliku primenu, zbog mnogobrojnih i različitih problema koji se svakodnevno javljaju u industriji. Metalizacija u određenim situacijama, može biti zamena drugim postupcima u cilju površinske zaštite materijala, kao što su: galvanizacija, cinkovanje, alitriranje, elektrostatičko nanošenje slojeva i dr. [3].

\section{Priprema supstrata}

Pre procesa nanošenja prevlake, metalizacijom, neophodno je pripremiti površinu uzorka. Prvi korak u pripremi je odmašćivanje površine. Površina uzorka se mora očistiti od masnoće, kako ne bi došlo do problema prilikom prianjanja prevlake na osnovni materijal. Od mnogobrojnih sredstava za odmašćivanje, koji su dostupni na tržištu, najčešće se koristi aceton, prvenstveno zbog dobre sposobnosti odmašćivanja kao i zbog činjenice da nije skup. Sledeći korak u pripremi površine je peskarenje, kako bi se postigla odgovarajuća hrapavost i uklonila eventualna korozija sa površine uzorka. U vlažnim sredinama, u kojima se odvija proces metalizacije, neophodno je izvršiti zagrevanje podloge, kako bi se uklonila vlaga sa površine. Međutim, ukoliko se podloga izloži povišenoj temperaturi predgrevanja, postoji mogućnost nastanka oksidacije, što može smanjiti jačinu veze između prevlake i supstrata. Nakon prethodno navedenih procesa, uzorak je spreman za metalizaciju. 


\section{PLAZMA METALIZACIJA U VAZDUHU (APS)}

Naziv plazma, proistekao je iz potrebe da se definiše stanje materije koje je dovedeno u parno stanje na viši energetski nivo od gasovitog stanja. Plazma nastaje dovođenjem energije sistemu u opsegu od $1 \mathrm{eV}$ do 10 $\mathrm{eV}$, pri čemu jedinica $1 \mathrm{eV}$ označava srednju kinetičku energiju toplotnog kretanja jednog molekula gasa na temperaturi $11.600 \mathrm{~K}$. Iz tog razloga, plazma predstavlja četvrto agregatno stanje sa velikom srednjom energijom po čestici [4].

Plazma metalizacija, kao jedna od najznačajnijih tehnologija za formiranje prevlaka, prisutna je u industriji punih 50 godina, a prva primena ovog postupka zabeležena je 1939. godine. Dugi niz godina, avio industrija je bila glavni korisnik plazma metalizacije, gde je kvalitet i sigurnost u eksploataciji bio najvažniji zahtev [5]. Tokom narednih godina, ova tehnologija našla je veliku primenu i u drugim granama industrije.

Najrasprostranjeniji postupak plazma metalizacije predstavlja APS, koji se odvija u atmosferskim uslovima, Slika 3. U literaturi, plazma metalizacija u vazduhu se javlja pod nazivom Atmospheric Plasma Spraying - APS ili Air Plasma Spraying - APS.

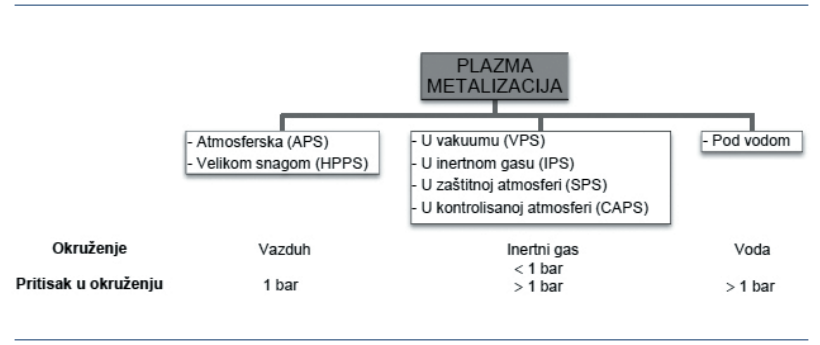

Slika 3. Podela postupaka plazma metalizacije u zavisnosti od radne sredine [6]

Ono što čini ovaj postupak najrasprostranjenijim je upravo široka paleta materijala koja može da se nanosi, što podrazumeva i keramičke materijale koji zahtevaju visoke temperature topljenja. Ovim postupkom je moguće nanositi velike količine rastopljenog materijala i do nekoliko kilograma na čas.

Kod plazma metalizacije u vazduhu, koristi se dodatni materijal u obliku praha, a prečnik čestica najčešće se kreće u opsegu od $10[\mu \mathrm{m}]$ do $100[\mu \mathrm{m}]$. Prilikom udara rastopljenih čestica o površinu radnog dela, Slika 4, dobijaju se lamele čija debljina iznosi nekoliko mikrometara i prečnika od nekoliko desetina do stotinu mikrometara. Kako bi se ostvario konzistentan površinski sloj, minimalna debljina prevlake mora biti oko $50[\mu \mathrm{m}][7]$.

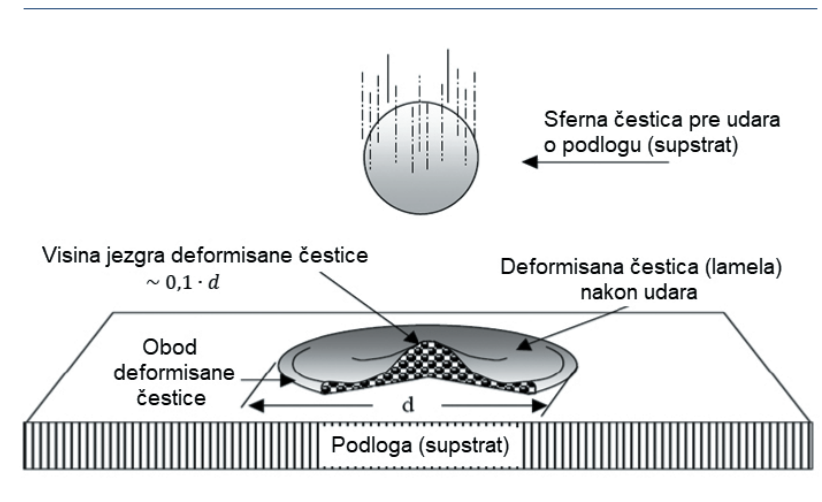

Slika 4. Udar rastopljene čestice u podlogu i formiranje lamele [8]

\section{OSNOVNA OPREMA PLAZMA METALIZACIJE U VAZDUHU}

Osnovna oprema plazma metalizacije u vazduhu, Slika 5, podrazumeva:

- boce za inertni gas,

- kompresor za vazduh,

- upravljačko - kontrolnu jedinicu,

- izvor električne energije,

- dozator praha,

- izmenjivač toplote za hlađenje pištolja,

- invertorski ispravljač,

- plazma pištolj.

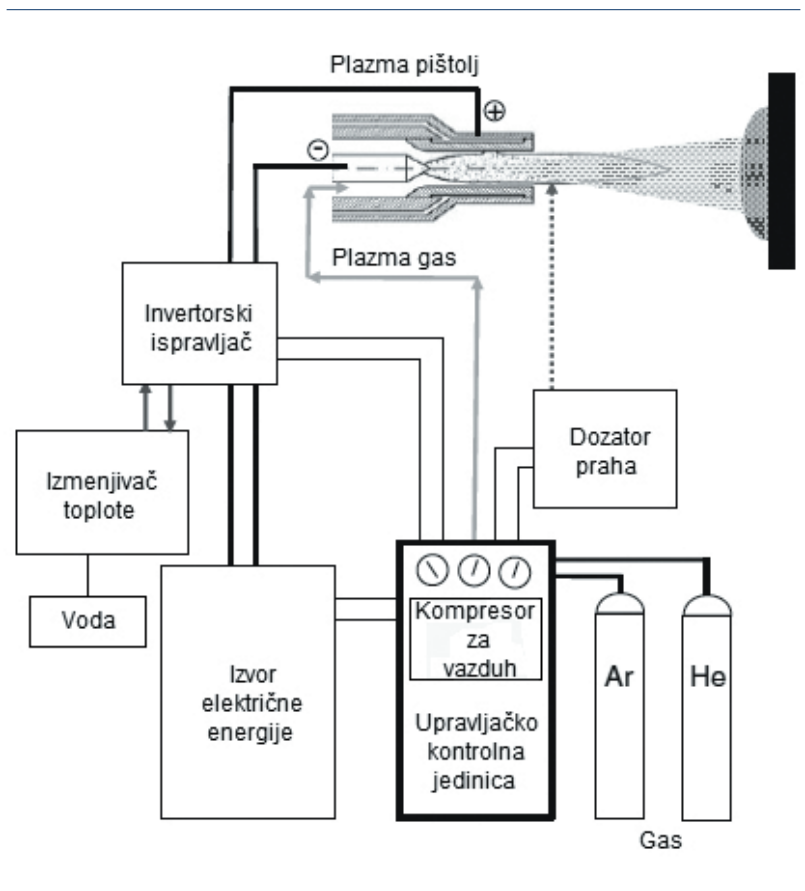

Slika 5. Osnovna oprema plazma metalizacije u vazduhu [9] 


\section{Gas za plazma metalizaciju}

U procesu plazma metalizacije u vazduhu, najčešće su korišćeni gasovi argon $(\mathrm{Ar})$ i azot $(\mathrm{N})$, a ponekad i u mešavini sa gasovima veće toplotne provodljivosti, kao što su vodonik $(\mathrm{H})$ i helijum $(\mathrm{He})$ ili viskoznosti, kao što je helijum (He) [7].

Za formiranje plazme u većini slučajeva koristi se argon kao inertni gas, jer on vrlo lako jonizuje, a zatim mu se dodaje vodonik. Dodavanje vodonika u argon vrši se iz razloga, jer se on razlaže na visokim temperaturama pre nego što dođe do procesa jonizacije atoma, a kao posledica toga dobija se veća energija plazme u poređenju sa plazmom dobijenom iz čistog argona.

\section{Plazma pištolj}

Pištolj za plazma metalizaciju predstavlja centralni deo sistema. On pretvara hemijsku, kinetičku i energiju električnog pražnjenja u toplotnu i/ili kinetičku energiju [9].

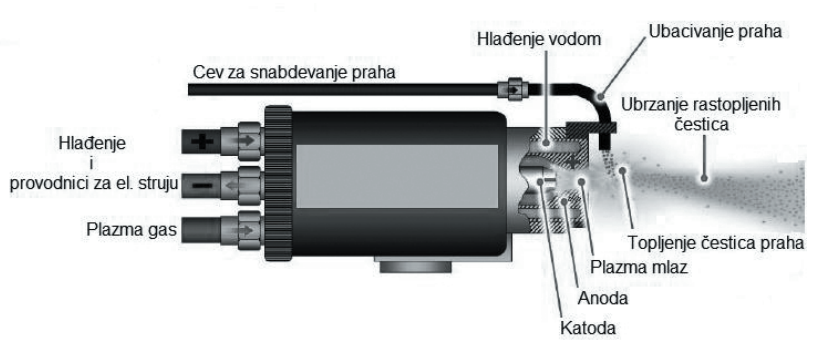

Slika 6. Pištolj za plazma metalizaciju u vazduhu [10]

Kod postupka plazma metalizacije u vazduhu, kao izvor toplote koristi se električni luk za formiranje plazme. Plazma mlaz se dobija propuštanjem inertnog gasa kroz električni luk, dobijen jednosmernom strujom, pri čemu je elektroda od volframa sa malim procentom torijuma i ima ulogu katode, dok je mlaznica od legure bakra i ima ulogu anode. Sudari atoma i molekula gasa, koji nastaju kao posledica visoke temperature u električnom luku, prouzrokuju jonizaciju atoma, što je praćeno oslobađanjem toplote i jake svetlosti, odnosno stvaranjem plazme [4]. Pištolj se tokom rada obavezno hladi vodom, zbog ekstremno visoke temperature, Slika 6.

Nakon formiranja plazme, na izlazu iz mlaznice pištolja, vrši se ubrizgavanje čestica praha. Čestice praha se ubrizgavaju pomoću injektora, koji u ovom slučaju predstavlja cev kružnog poprečnog preseka, unutrašnjeg prečnika $1,2[\mathrm{~mm}]$ do $2[\mathrm{~mm}]$, Slika 6. Cev za snabdevanje praha i u slučaju kada je hlađena vodom, ne sme biti postavljena blizu plazma mlaza, kako ne bi došlo do začepljenja zbog visoke temperature plazme. Ukoliko se smanji prečnik čestica praha, neophodno je povećati protok gasa, jer kod praha, gde je prečnik čestica manji, gas može da remeti plazma mlaz [11].

$\mathrm{Na}$ slici 7 prikazana je raspodela temperature u mlazu plazme. Uočava se da temperatura u jezgru plazme može biti i preko $30.000 \mathrm{~K}$, dok sa povećanjem rastojanja od mlaznice, temperatura značajno opada, pa pri vrhu mlaza njena vrednost opadne i više od 10 puta u odnosu na jezgro.

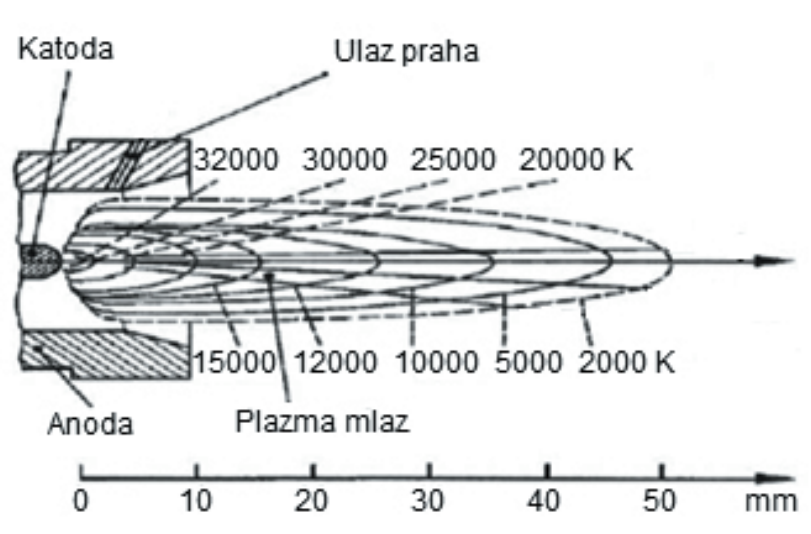

Slika 7. Raspodela temperature u mlazu plazme [6]

Dodatni materijal, u ovom slučaju prah, nošen gasom se ubrizgava u formiran mlaz plazme, Slika 8. Mesto gde prah ulazi u pištolj, isključivo zavisiti od konstrukcionog rešenja pištolja i može biti postavljeno pod različitim uglovima u odnosu na osu plazme. Čestice praha koje su manjeg prečnika veoma teško ulaze u jezgro plazme zbog male kinetičke energije, dok sa druge strane, čestice praha većih dimenzija prolaze kroz plazma mlaz pri čemu se nekada ne rastope u potpunosti [12].

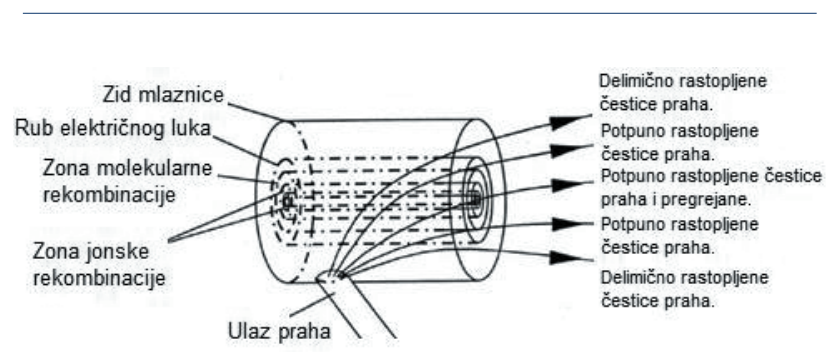

Slika 8. Različite putanje čestica nakon ubrizgavanja u plazma mlaz [12] 
Tokom rada, potrebno je pištolj držati u odgovarajućem položaju, kako bi rastopljene čestice praha udarale pod uglom od $90^{\circ}$ u površinu uzorka. Rastojanje između pištolja i suptrata je najčešće od 100 do 150 [mm], što zavisi od primenjenih materijala i parametara metalizacije. Rastojanje između supstrata i pištolja mora da bude dovoljno veliko kako bi se obezbedilo potpuno topljenje dodatnog materijala, dok sa druge strane, preveliko rastojanje pištolja od osnovnog materijala može prouzrokovati prevremeno očvršćavanje rastopljenih čestica, što $\mathrm{u}$ oba slučaja prouzrokuje stvaranje neistopljenih čestica $\mathrm{u}$ formiranoj prevlaci. Primer parametara korišćenih tokom nanošenja prevlake plazma metalizacijom u vazduhu, prikazani su u tabeli 1 [13].

\begin{tabular}{lc}
\hline \multicolumn{1}{c}{ Parametri nanošenja } & Vrednosti \\
\hline Protok osnovnog gasa (argon), 1/min & 47 \\
\hline Protok pomoćnog gasa (helijum), l/min & 12,5 \\
\hline Jačina struje, A & 800 \\
\hline Napon strujnog luka, V & 37 \\
\hline Protok nosećeg gasa (argon), 1/min & 7 \\
\hline Količina unetog praha, g/min & 40 \\
\hline Rastojanje pištolja od supstrata, mm & $90 / 100 / 110$
\end{tabular}

Rastojanje pištolja od supstrata, mm

Tabela 1. Primer parametara korišćenih u toku postupka APS [13]

Plazma pištolja ima veliku i značajnu primenu u industriji, međutim potrebno je izdvojiti tri osnovna nedostatka, a to su: nestabilnost električnog luka, preveliko trošenje elektroda kao i radijalno ubrizgavanje praha. Prethodnih godina, pa i danas, intenzivno se radi na istraživanju aksijalnog ubrizgavanja čestica praha u središte mlaza plazme [7].

\section{MATERIJALI ZA FORMIRANJE PREVLAKE}

U procesu plazma metalizacije u vazduhu, najčešće korišćeni materijali u vidu radnih komada su keramički i metalni materijali, a kao dodatni materijali za formiranje prevlake koriste se gotovo svi metali, pa u velikoj meri i nemetali. Veoma je važno istaći, da tokom procesa plazma metalizacije, materijal koji se koristi za formiranje prevlake ne sme da isparava niti da bitno menja svoja svojstva. Izbor dodatnog materijala od kojeg će biti formirana prevlaka direktno zavisi od uslova rada mašinskog dela.
Osnovna prednost materijala koji se koristi u obliku praha, jeste upravo relativno niska cena kao i jednostavna tehnologija dobijanja istog. Izbor praha, odnosno vrsta prevlake, predstavlja najvažniji korak u procesu plazma metalizacije u vazduhu, koji zavisi od sledećih faktora:

- vrste supstrata i geometrijskog oblika radnog dela,

- željene karakteristike formirane prevlake,

- radnih uslova,

- ostvarene debljine prevlake,

- tehnologije obrade prevlake,

- stanja površine nakon formiranja prevlake [4].

S obzirom da temperatura u plazma pištolju može dostići vrednost od $16.000{ }^{\circ} \mathrm{C}$, teško topljivi materijali ne predstavljaju problem prilikom formiranja prevlake ovim postupkom. Sa aspekta veličine čestica praha, one variraju u zavisisnosti od vrste materijala, pa se tako čestice praha za keramičke materijale kreću u opsegu 5 do $50[\mu \mathrm{m}]$, dok za legure metala veličine čestica su u opsegu 20 do 120 [ $\mu \mathrm{m}]$ [14]. Na slici 9 je prikazan primer praha, austenitnog nerđajućeg čelik 316L, snimljen skenirajućim elektronskim mikroskopom (SEM) sa veličinom čestica oko $60[\mu \mathrm{m}]$.

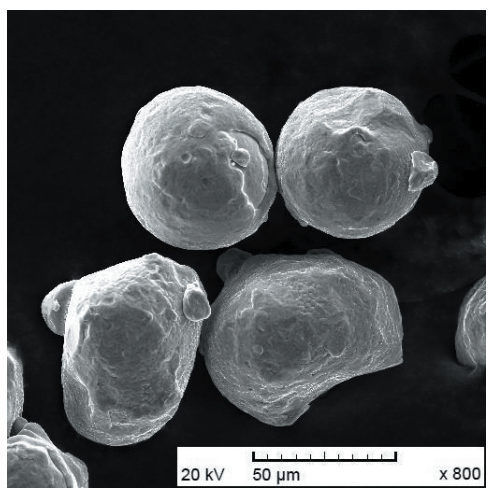

Slika 9. Austenitni nerđajući čelik 316L, SEM uvećanje 800 puta

Imajući u vidu da veličine čestica praha, koje se koriste u procesu plazma metalizacije u vazduhu, nisu iste te da i one nisu pravilnog oblik, može da predstavlja problem prilikom transporta iz bunkera u pištolj. Pojava prslina kao i odvajanje prevlake od supstrata, posledica je prevelike debljine u odnosu na predloženu vrednost za dati materijal. Nepotpuno vezivanje rastopljenih čestica u sloju, posledica je takođe veće debljine prevlake kao i nanošenje slojeva prevlake u etapama. Iz tog razloga pogodnije je nanošenje slojeva kontinualno. 


\section{OBLAST PRIMENE PREVLAKA DOBIJENIH PLAZMA METALIZACIJOM U VAZDUHU}

Prevlake dobijene procesom plazma metalizacije $\mathrm{u}$ vazduhu nalaze veliku primenu u industriji, pri čemu treba posebno izdvojiti:

- automobilsku industriju,

- hemijsku industriju,

- avio industriju,

- prehrambenu industriju,

- procesnu industriju i dr.

Nanošenje prevlaka primenom APS postupka, pored velike primene u proizvodnji novih delova, nalazi veliku potrebu i u reparaciji mašinskih delova, kako bi se vratile dimenzijske tolerancije kao i poboljšala površinska svojstva materijala.

\section{MEHANIZMI VEZE}

Mehanizmi veze koji nastaju između osnovnog materijala (supstrata) i prevlake, formirane procesom plazma metalizacije, u potpunosti nisu jasni. Smatra se da nastaju istovremenim delovanjem mehaničkog povezivanja i difuzione veze. Pored prethodno navedenih veza, deluju i drugi mehanizmi vezivanja kao što su adhezivne, hemijske i fizičke kao i Van der Valsove veze. Najvažniji faktori koji utiču na uspešno vezivanje i formiranje prevlake su: čvrstoća površine, profil površine, temperatura (termička energija), vreme (brzina reakcije i hlađenja), brzina čestica (kinetička energija), fizičke i hemijske osobine čestica kao i fizičko-hemijske reakcije [15].

Kako bi se postigla što bolja adhezija između formirane prevlake i radnog dela, pa i u određenoj meri smanjila površinska naprezanja usled udara rastopljene čestice o podlogu, potrebno je da podloga bude ohrapavljena, odnosno da hrapavost površine bude $10 \pm 2[\mu \mathrm{m}]$ [16].

Prevlake koja se formiraju iz potpuno ratopljenih čestica praha, nastalih procesom plazma metalizacije, dovode do obrazovanja potpune metalurške veze kako između rastopljenih čestica tako i između osnovnog materijala i rastopljenih čestica praha.

Problemi se mogu pojaviti kod nanošenja keramičke prevlake na metalnu podlogu, zbog loše adhezije, a kao rešenje moguće je nanošenje međusloja između podloge i keramičke prevlake [17].

\section{POROZNOST I OKSIDACIJA U PREVLAKAMA}

Mikrostruktura prevlake, dobijena postupkom plazma metalizacije u vazduhu, Slika 10, je lamelarna, koju čine deformisane čestice praha i oksidi između izduženih čestica [18].

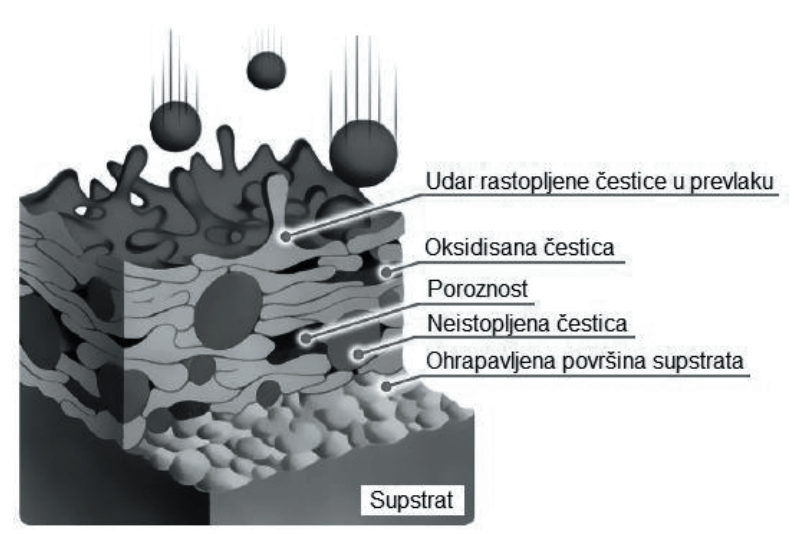

Slika 10. Poprečni presek prevlake formirane postupkom APS [10]

Poroznost je prisutna kod velikog broja prevlaka nenesenim postupcima termičkog raspršivanja, što podrazumeva i primenu plazma metalizacije u vazduhu. Udeo poroznosti u prevlaka najčešće se kreće od 1 do $5 \%$, pri čemu se na poroznost može uticati promenom parametara u toku procesa metalizacije kao i samim izborom materijala. Poroznost se u prevlakama javlja kao posledica: male udarne energije (nerastopljene čestice i male brzine), efekta zasenčenja (nerastopljene čestice i ugao raspršivanja praha) kao i skupljanja materijala [19].

Tokom procesa plazma metalizacije u vazduhu većina metalnih materijala, koja se koristi u procesu formiranja prevlake, podložna je oksidaciji. Naime, metalne čestice koje se kreću kroz vazduh, oksidišu po svojoj površini, stvarajući oksidnu ljusku. Oksidi, koji nastaju kao posledica oksidacije, jasno su vidljivi u poprečnom preseku prevlake i njihovo prisustvo u prevlaci doprinosi povećanju tvrdoće, a samim tim i otpornosti na habanje. Međutim, prisustvo oksida utiče negativno na kvalitet prevlake, jer olakšava nastanak korozije, utiče na pad čvrstoće same prevlake kao i lošu mašinsku obradljivost. Sa povećanjem veličine čestica praha povećava se poroznost, dok sa smanjenjem veličine čestica praha raste oksidacija [19]. 


\section{NAPONI U PREVLAKAMA}

Tokom procesa plazma metalizacije u vazduhu, zbog ekstremno visokih temperatura plazme, materijali koje se koriste za formiranje prevlake biće izloženi zagrevanju. Rastopljene čestice praha, prilikom udara o osnovni materijal počinju da se hlade i očvršćavaju. Hlađenje i očvrćavanje većine materijala praćeno je skupljanjem, a kao posledica toga dolazi do pojave zateznih napona unutar čestica i pritisnih napona unutar površine podloge, odnosno supstrata. Tokom nanošenja slojeva prevlake, odnosno tokom njenog nadgrađivanja, rastu i zatezni naponi u prevlaci, koji u određenom trenutku, kada se ostvari velika debljina prevlake, mogu postati veći od čvrstoće same veze, što će prourokovati lom prevlake. Proces nastanka loma prevlake, kao posledica zateznih napona u njoj, prikazan je hronološki na Slici 11. Generalno, može se reći da su tanke prevlake dugotrajnije u poređenju sa prevlakama velikih debljina.

a)

Zatezno opterećenje deluje na supstrat usled skupljanja čestice praha

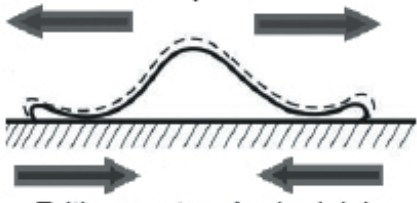

Pritisno opterećenje deluje na supstrat nakon nanošenja čestice

b)

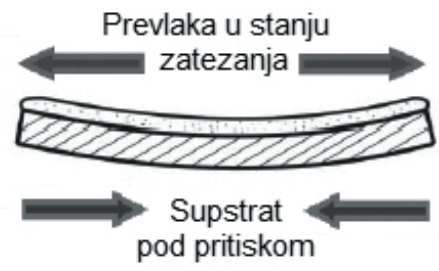

c)

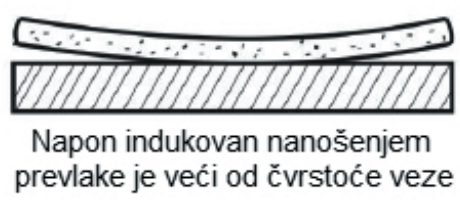

Slika 11. Hronološki prikaz nastanka loma prevlake [20]

\section{UTICAJ TEMPERATURE BRZINECESTICA NA PREVLAKU}

Brzine rastopljenih čestica kao i temperature plamena u procesu metalizacije, imaju najznačajniju ulogu u formiranju gustine prevlake. Na Slici 12, prikazan je položaj plazma metalizacije u vazduhu - APS, u odnosu na neke od postupaka metalizacije.

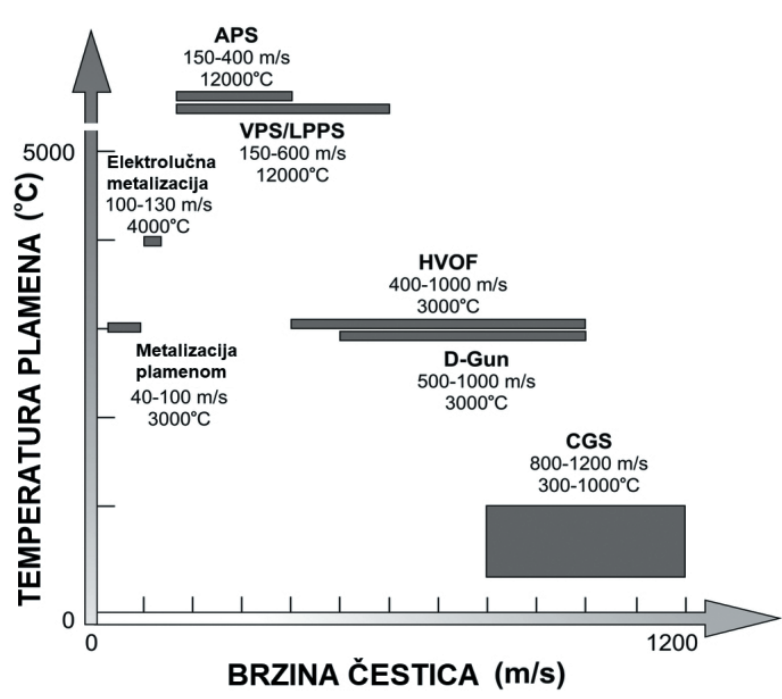

Slika 12. Temperatura i brzina čestica kod plazma metalizacije u vazduhu [21]

Temperatura plazme je značajno veća od temperature koju mogu da ostvare drugi postupci metalizacije, što omogućava nanošenje slojeva teško topljivih materijala, kao što su keramički materijali. Važno je napomenuti, da sa povećanjem brzine kretanja rastopljenih čestica se povećava kako gustina formirane prevlake tako i adheziona sila između osnovnog materijala i prevlake.

Fizičke karakteristike formirane prevlake su u funkciji brzine i temperature nanošenja praha procesom plazma metalizacije. Ukoliko je brzina čestica praha mala tada neće doći do formiranja kontinualne prevlake, dok primenom velikih brzina čestica može dođi do erozije površina radnog dela.

Na slici 13, prikazan je sveobuhvatni uticaj plazma metalizacije u vazduhu, što jasno ukazuje na činjenicu, zbog čega je ovaj postupak jedan od najprimenjivijih u industriji. 


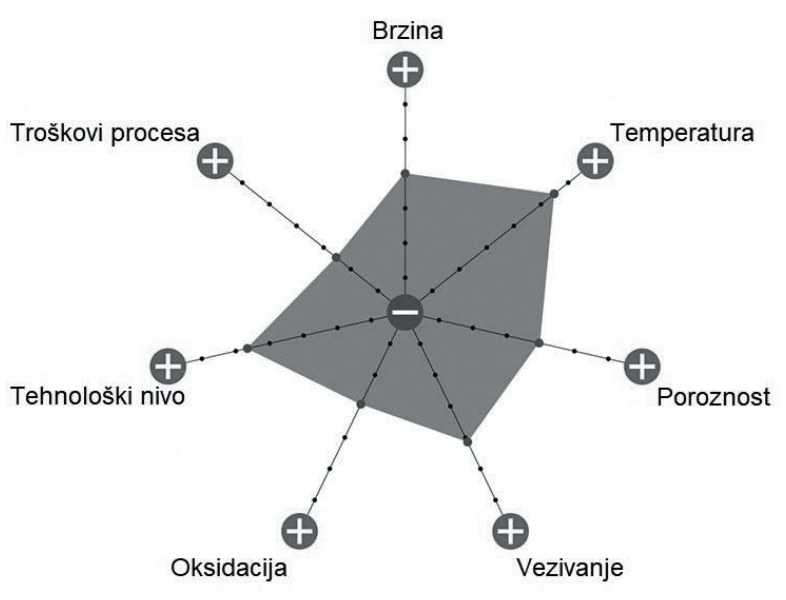

Slika 13. Sveobuhvatni uticaj plazma metalizacije u vazduhu [10]

\section{ZAKLJUČAK}

Različiti su razlozi nanošenja prevlaka na mašinske delove, ali kao osnovni i najvažniji može se istaći produžetak radnog veka. Mašinskim delovima i konstrukcijama, mogu se poboljšati površinska svojstva materijala upravo nanošenjem prevlaka u cilju izlaganja oštrijim ili promenljivim režimima rada.

Razvoj procesa plazma metalizacije u vazduhu, doprineo je povećanoj produktivnosti nanošenja dodatnog materijala uz postizanje zadovoljavajuće ravnomernosti i jednolikosti formiranih prevlaka. Osnovna prednost ovog postupka je mogućnost nanošenja široke palete materijala, pri čemu je naročito pogodan za nanošenje materijala koji zahtevaju visoke temperature topljenja. Kao rezultat procesa APS, formiraju se prevlake visokog kvaliteta, pogodne za primenu gotovo u svim granama industrije.

Podaci iz savremene literature, pokazuju da je procesom plazma metalizacije moguće produžiti radni vek mašinskih delova i opreme i do 10 puta, pri čemu treba imati u vidu da cena takvih konstrukcija nije mala, što će direktno uticati na smanjenje troškova održavanja postrojenja.

\section{ZAHVALNOST}

Ovaj rad proistekao je iz rezultata istraživanja na projektu Ministarstva prosvete, nauke i tehnološkog razvoja Republike Srbije TR 35024.

\section{LITERATURA}

[1] B. Rajičić, G. Bakić, M. Đukić, V. Šijački-Žeravčić, M. Braunović, and B. Anđelić, "Overview of Advanced Methods of Boiler Tubes Erosion Protection," International Conference Power Plants 2012, Serbian Society of Thermal Engineers (2012), October, 30th - November, 2nd, pp. 1-10, Zlatibor, Serbia, 2012.

[2] Thermal Spray Solutions [homepage on the Internet]. The Virginia: Thermal Spray 101 [cited 2018 March 15]. Available from: http://www.thermalsprayusa.com/.

[3] D. Mišović, "Regeneracija metalizacijom plazma postupkom," Vojnotehnički glasnik/Military Technical Courier (ISSN 0042-8469), vol. 41, pp. 32-39, Januar-Februar 1993.

[4] J.D. Dautović, "Possibility to regenerate parts of ship gas turbine engines using the plasma metallization process," Vojnotehnički glasnik/Military Technical Courier (ISSN 0042-8469), vol. 60, pp. 266-283, January-March 2012.

[5] J.R. Davis, Handbook of Thermal Spray Technology: Introduction to Thermal Spray Processing. Materials Park (USA), Thermal Spray Society and ASM International (ISBN 0-87170-795-0), 2004, pp. 3-13.

[6] O. Knotek, Handbook of Hard Coatings: Thermal spraying and detonation gun processes, in R.F. Bunshah. New York, Noyes Publications/William Andrew Publishing, LLC Norwich, 2001.

[7] A. Vardelle, C. Moreau, N.J. Themelis, and C. Chazelas, "A Perspective on Plasma Spray Technology," vol. 35, Plasma. Chem. Plasma. P., Springer Science+Business Media, New York, 2014, pp. 491-509.

[8] J. Stokes, The Theory and Application of the SULZER METCO Diamond Jet HVOF Thermal Spray Process. Dublin, Dublin City University, 2003.

[9] P.L. Fauchais, J.V.R. Heberlein, and M.I. Boulos, Therma Spray Fundamentals From Powder to Part. New York, Springer Science+Business Media, 2014.

[10] Flame Spray Technologies BV [homepage on the Internet]. The Netherlands: Thermal Spray systems \& equipment [cited 2018 March 15]. Available from: https://www.fst.nl/.

[11] P. Fauchais, "Understanding plasma spraying," J. Phys. D. Appl. Phys., vol. 37, pp. 86-108, 2004.

[12] E. Lugscheider, Handbuch der termischen Spritztechnik: Tehnologien - Werkstoffe - Fertigung. Düsseldorf, Verlag für Schweißen und verwandte Verfahren DVS-Verlag GmbH, 2002.

[13] M. Mrdak and A. Vencl, "Influence of the deposition parameters on mechanical properties and structure of $\mathrm{NiCr}$ coating deposited by atmospheric plasma spraying," Tehnička dijagnostika (ISSN 1451-1975), vol. 10, pp. 9-14, 2011. 
[14] S. Brossard, P.R. Munroe, A.T.T. Tran, and M.M. Hyland, "Study of the effects of surface chemistry on splat formation for plasma sprayed $\mathrm{NiCr}$ onto stainless steel substrates," Surf. Coat. Tech., vol. 204, pp. 1599-1607, 2010.

[15] H. Herman, S. Sampath, and R. McCune, "Thermal Spray: Current Status and Future Trends," Mrs. Bull., vol. 25, pp. 17-25, 2000.

[16] M.S. Morsi, S.A. Abd El Gwad, M.A. Shoeib, and K.F. Ahmed, "Effect of Air Plasma Sprays Parameters on Coating Performance in Zirconia-Based Thermal Barrier Coatings," Int. J. Electrochem. Sc., vol. 7, pp. 2811-2831, 2012.

[17] N. Hegazy, M. Shoeib, S. Abdel-Samea, and H. Abdel-Kader, "Effect of Plasma Sprayed Alumina Coating on Corrosion Resistance," 13th International Conference on Aerospace Sciences \& Aviation Technology, Paper: ASAT-13-MS-14, pp. 1-10, May 26-28 2009.
[18] B.S. Schorr, K.J. Stein, and A.R. Marder, "Characterization of Thermal Spray Coatings," Mater. Charact., vol. 42, pp. 93-100, 1999.

[19] V. Šijački-Žeravčić, M. Đukić, G. Bakić, and B. Rajičić, "Reparacija mašinskih delova i konstrukcija: Postupci termičkog raspršivanja - Metalizacija," University of Belgrade Faculty of Mechanical Engineering, in press.

[20] Nature of Thermal Spray Coatings - Gordon England [homepage on the Internet]. The England: Thermal Spray Processes [cited 2018 March 15]. Available from: https://www.gordonengland.co.uk/.

[21] M. Oksa, E. Turunen, T. Suhonen, T. Varis, and S.P. Hannula, "Optimization and Characterization of High Velocity Oxy-fuel Sprayed Coatings: Techniques, Materials, and Applications," Coatings., vol. 1, pp. 17-52, 2011. 